\title{
Representation through deliberation - The European case
}

By

Erik Oddvar Eriksen and John Erik Fossum

Address:

ARENA, University of Oslo

P.O. Box 1143 Blindern

N-0318 Oslo

Norway

e.o.eriksen@arena.uio.no

j.e.fossum@arena.uio.no

Phone \# (Eriksen): +4722858870

(Fossum): +47 22858881

Fax \#: +47 22858710

\begin{abstract}
This article shows that the main pattern of European democratization has unfolded along the lines of an EU organized as a multilevel system of representative parliamentary government and not as a system of deliberative governance as the transnationalists propound. But the multilevel EU has developed a structure of representation that is theoretically challenging. In order to come to grips with this we present an institutional variant of deliberative theory, which understands democracy as the combination of a principle of justification and an organizational form. It comes with the following explanatory mechanisms: claimsmaking, justification and learning which in the EU also program institutional copying and emulation mechanisms. We show that the EU has established an incomplete system of representative democracy steeped in a distinct representation-deliberation interface, which has emerged through a particular and distinct configuration of democratization mechanisms.
\end{abstract}

Paper to be presented at the $12^{\text {th }}$ EUSA Biennial International Conference, Boston, MA, March 35,2011 


\section{Introduction}

The European Union is a deeply contested political entity, also in democratic terms. It has a democratic vocation, but the EU is not a state, and the democratization process has not unfolded along the lines of nation-state-based democracy. The Union then also lacks important democratic enabling conditions, such as a nation, a pre-political people, and a collective European identity based on a common language and culture. Analysts point to the absence of a European demos, but are puzzled by the high degree of compliance in the absence of the 'kratos' of the 'demoskratos'. Transnationalists such as Joshua Cohen and Charles Sabel and James Bohman claim that the European Union has democratic qualities which relate to its distinct polity traits. ${ }^{1}$ As a polycentric system of networked governance the Union's democratic potential, in their view, emanates from its ability to deter domination, and to develop democratic forms that differ from state-based modes of representative democracy. The most suitable and promising form of democracy for such an innovative configuration is not representative government but rather direct-deliberative polyarchy ${ }^{2}$ or a transnational multiple-demoi mode of deliberative democracy. $^{3}$

Against this, numerous analysts including for instance Berthold Rittberger, ${ }^{4}$ Simon Hix et al., ${ }^{5}$ Julie Smith, ${ }^{6}$ and Glyn Morgan ${ }^{7}$ have underlined that EU democratization has unfolded in a more state-like hierarchical fashion along representative-democratic lines, as manifested in the development of the EP and in the consolidation of representative democracy in the Member States.

Our point of departure is that the main thrust of EU democratization has unfolded along representative-democratic lines but within a government-type organisation which falls well short 
of sovereign statehood, but still includes stronger elements of stateness than a mere transnational governance arrangement. ${ }^{8}$ In that sense we agree with Rittberger and Hix that the EU's representative-democratic thrust is readily apparent in its democratic self-conception; it is also that form of democracy that the EU has entrenched in its institutional-constitutional structure; and it is the democratic form that most critics evaluate the EU against. The European Parliament is directly elected by the EU's citizens (as the only supranational parliament in the world); it is a co-legislator with the Council in a wide range of issue-areas; and it is also able to hold the Commission accountable. This development has not produced a full-fledged EU system of representative democracy, but the EP's development nevertheless exhibits a clear trend towards a more explicit parliamentarianism at the EU-level.

The EU's strong parliamentary thrust runs against the transnational governance position on EU democratization. But this development exhibits distinct traits that are not well enough picked up by those that underline the strong EU representative thrust. ${ }^{9}$ The EU has developed a distinct multilevel representative structure which falls short of but also clearly differs from the two-channel structure that is characteristic of federal systems (where one channel links the citizens to the federal level and the other to the state/province/Land level). The EU's representative structure is more akin to a multilevel parliamentary field, ${ }^{10}$ where the EP is tightly linked with the national parliaments through structured patterns of communication and interaction. ${ }^{11}$ These observations suggest that there is merit in the transnationalists' emphasis on deliberation but the process has taken a different institutional form than what they propound.

Consequently, in this article we argue that the EU's democratization is best understood when considered from a deliberative approach, but through a special institutional version of deliberative theory that is geared to representative democratic institutional arrangements. The theory adds to existing accounts because it provides a better account of the distinct and 
characteristic feature of EU integration, namely that it unfolds in a setting of already established representative democracies. Europeans derive their understanding of modern democracy from this institutional-constitutional setting; it has figured as a major institutional resource and impetus for the EU's democratization; and this understanding has implications for how we should conceptualize democratization.

In this article we first outline this institutional version of deliberative democratic theory, which comes with the following explanatory mechanisms: claims-making, justification and learning which also deliberatively encode copying and emulation mechanisms. Throughout we briefly apply it to the EU to demonstrate its relevance for the distinct pattern of democratization that the EU has thus far undergone. In the concluding section we present some of the implications that a multilevel system of tightly interwoven parliaments brings up for the theory and practice of representative democracy.

\section{Democratization through deliberation}

Deliberative theory is premised on the force of reason-giving in collective decision-making processes. The actors coordinate their actions through giving and responding to reasons. How then to think of democracy and democratization from a deliberative perspective?

In order to address this we start from the understanding of deliberative theory that also transnationalists embrace, namely that democracy is foremost a higher-order legitimation principle, which sets out the requisite conditions for justification. It is first and foremost a principle, or a critical standard, that sets down the conditions for how to get things right in the political sphere of action. In democracies, only public deliberation can get political results right, as it entails the act of justifying the laws to the people who are bound by them. On the most 
fundamental level, deliberation and not voting, is the currency of democracy, as one needs to argue for the use of other decision-making procedures. ${ }^{12}$ Democratic systems contain provisions to ensure that prior to aggregative procedures, extensive processes of discussion and opinion formation can take place. ${ }^{13}$

This in no way denies the importance of voting and other formal systems of representation and decision-making. Without formal-legal egalitarian procedures of law-making there is no democracy. ${ }^{14}$ Deliberation in itself cannot bear the entire burden of democratic legitimation because it is impossible to meet the requirement of having the legal norms accepted by all affected parties in a free and open debate. Only with law-making procedures and political institutions in place can citizens effectively influence the laws that affect them, and determine whether the reasons provided are good enough. The raison d'être of democratic procedures is to produce good and fair results, but results do not justify themselves. They rest on prior political decisions and are themselves in need of justification. Under modern conditions, only procedures can lend legitimacy to results. ${ }^{15}$ The deliberative perspective thus comes with a set of legalinstitutional and procedural prerequisites. The most basic are: (a) a constitution with a set of inalienable rights; (b) fora for public debate; and (c) institutional mechanisms to transform political initiatives into collective commitments in a representative manner.

This recognition has prompted us to develop an institutional variant of the deliberative perspective. As we will show, this perspective is particularly apposite to understand democratization in the EU which unfolds in a setting marked by a high density of democratic norms and principles - institutionally entrenched at the Member State level (and increasingly transferred to the EU-level).

We accordingly understand democracy to combine a principle of justification with an organisational form for the handling of common affairs. Effective operation of the democratic 
principle has to take an organisational form that will be capable of sustaining a set of properly delimited legislative, sanctioning and executive powers. This to a large extent makes up the very semantic of modern democracy, and is reflected in the global prevalence of representative (parliamentary) state-based democracy. The distinction between democracy as a principle of justification on the one hand, and as an organisational form on the other, helps to make sense of the democratic salience that modern societies attribute to parliamentarianism.

The parliamentary organisational form is a real-life approximation to the democratic principle; thus the parliamentary principle is tied in with the principle of justification. The greater the normative thrust of the parliamentary principle, then, the easier it is for people to take it for granted that there is a close association between democracy and parliamentary democracy (as a specific institutional version of democracy). Representative (parliamentary) democracy has come to figure at the heart of modern democracy; this is certainly the case in the EU where every Member State is a constitutional representative democracy. Only democratic states will qualify for EU membership.

Deliberative democracy in our reading, then, entails offering justifications to citizens, in light of agreed-upon standards. ${ }^{16}$ We have already identified the parliamentary principle as one such; it in turn forms part of a broader set of institutional-constitutional arrangements. What is the normative thrust of such arrangements?

\section{The thrust of parliamentary democracy}

Legal arrangements and democratic procedures establish choice opportunities, meeting places and behavioural constraints, but also the basic language codes or symbolic categories necessary for actors to sort out common affairs through rights and procedures. They constitute a common language - a medium - through which actors can reach agreement on collective commitments. 
Democracy, the rule of law, and human rights, with their wider corollaries as the separation of powers, responsible government, and elections, are the discursive codes of political institutions that stem from the common constitutional traditions of the EU's Member States. They are deeply embedded in the pan-European, Western political culture. Such codes provide a common ground for actors to entrust each other. When properly entrenched in institutions and procedures, actors can be swayed by the force of the better argument or come to respect compromises and outcomes that are detrimental to their interests.

Among the democratic procedures, parliament enjoys a special status, as it is frequently seen as the embodiment of democratic rule tout court. It embodies the idea of joint selfdetermination in that an elected body of responsible citizens is there to legislate in the name of all. The parliamentary principle combines rules for inclusion of those affected with rules for deliberation and voting that aim at ensuring public debate, as well as reaching collectively binding decisions within a given time limit. Parliament is, according to Guizot, 'the place in which particles of reason that are strewn unequally among human beings gather themselves and bring public power under their control' ${ }^{17}$ The parliamentary principle connects to the modern legitimation principle of government by discussion as it is founded on deliberative rational principles. ${ }^{18}$ It satisfies many of the conditions for critical justification of political power when properly institutionalized as a deliberative body - a strong public ${ }^{19}-$ with open channels to the public sphere rooted in civil society. It combines participatory and epistemic functions, and may thus be seen to warrant the presumption of rational and generally acceptable results.

In modern polities, public deliberation is wed to systems of representation, as no system can accommodate the participation of all the relevant stakeholders. Representation refers to procedures and processes for citizens to influence political decision making and the actions of public officials in manners generally considered to be legitimate. For large-scale societies, 
representative democracy revolving on a deliberative assembly at its heart offers the possibility for 'government by and of the people', insofar as it ties in with free opinion-forming processes in civil society. In a democracy the legitimating principle of political rule is the citizens' consent. The institutional nexus that is vital for forming, mediating, and executing citizens' will, at the same time faced with an increasingly complex political agenda, has a strong proclivity to liberate itself from democratic constraints and become independent. The parliament is a vital means for ensuring the proper mediation between the citizens and the political institutions. It serves the dual function of institutionalizing 'the will of the people' and ensures that the policies enacted by the executive are grounded in this will. It is a system in which the process of deliberation is institutionalized and subjected to procedural constraints to such a degree that the citizens do not govern themselves directly. Rather, laws and collective decisions made by a representative body are subjected to the test of public reason - public inquiry and scrutiny - to the judgment and 'the verdict of the people. ${ }^{20}$ Parliamentarianism does not exhaust the principle of democracy but operationalizes it and makes it fit for the real world or for non-ideal situations: parliamentarianism transforms democracy into feasible criteria of popular sovereignty and political equality.

The rationale of parliament rests on a 'dynamic-dialectic' of argument and counterargument, of public debate and discussion. Deliberation is intrinsic to the mode of representation that parliaments are based on, and enables government by discussion. John Stuart Mill noted that: 'When it is necessary, or important to secure hearing and consideration to many conflicting opinions, a deliberative body is indispensable. ${ }^{21}$ The deliberative principle of representation can be stated as follows: 'no proposal can acquire the force of public decision unless it has obtained the consent of the majority after having been subjected to trial by discussion. ${ }^{22}$ Hence, the modern conception of representation can be said to be parasitic on deliberation. No person can 
consider herself to be legitimately represented unless the mandate and accountability terms are spelled out, and the represented are offered acceptable justifications for decisions taken on their behalf.

How is the parliamentary principle reflected in the European democratisation process?

\section{The emergence of the European parliament}

Today, in the EU context, democracy and human rights are not only unavoidable as the means for interpreting the EU's recent history and as the means for defining what it is about - its identity; they also constitute the very language codes for dealing with common affairs, with roots back to the EU's very beginning. What is also notable is that the parliamentary principle, which comprises rules that regulate representation, the establishment and composition of political bodies, procedures, hearings, and decision-making, figured centrally from the EU's very inception. Representative democracy has found its strongest manifestation in today's European Parliament which developed from the body initially labelled the European Assembly, and which was set up in 1951. The parliamentary principle was proclaimed early on. This use of normative language helped to create an action-reinforcing process which over time gave institutional shape to the parliamentary principle in a non-state supranational setting: 'In choosing to call itself a 'parliament', the Assembly was not so much pretending to be a parliament as clearly pointing out that it wanted to become one. The same logic lay behind the name change from European Assembly to European Parliament in the Single European Act: the Member States were not so much declaring that the Assembly was a parliament as effectively recognising that it should

become one. ${ }^{, 23}$ With the principle thus entrenched, the EP reinforced by supportive actors and institutional arrangements has pursued a lengthy and drawn-out struggle for recognition, which includes efforts to strengthen its position vis-à-vis the Commission and the Council, and the 
Member State governments. This process was one where central elements of the parliamentary organisational form were copied onto the European level. This struggle was justified with reference to the Union's dual legitimacy, a Union made up of citizens and of states.

In Europe, the very term constitutionalisation has come to mean 'the embedding of principles related to representative party-based democracy into the treaties; ${ }^{, 24}$ it entails '...the development of representative parliamentary institutions and the codification of fundamental rights. 25

The development of EU-level representative democracy took place through a gradual and stepwise process, which is still short of fruition. The EP was an important driver in this process, but it was also as we shall see given vital support from a range of institutions and procedures at the Member State and EU levels, as well as from societal actors. In the first decades this was still foremost an institution-driven process, with little direct public input. In fact, prior to the early 1990s there had been little public discussion about the then EC's democratic credentials. ${ }^{26}$

In many ways, the ratification of the Maastricht Treaty (1992) was the 'triggering moment' when the corollaries of democracy, such as electoral control, separation of powers, and executive accountability (the discursive codes of political institutions that stem from the common constitutional traditions of the EU's Member States), became publicly flagged as the common categories of understanding and the joint evaluation standards that the actors should use when dealing with the EU. These were far from new with Maastricht but Maastricht amplified them through greatly increased public exposure. The Maastricht Treaty ratification process helped to shift the terms of discourse in that it made vital aspects of these common constitutional traditions of the Member States - notably fundamental rights and representative democracy - relevant for the $E U$ as the proper operating procedures and as the appropriate criteria for normative evaluation. The Treaty of Maastricht and the response to the popular reaction underlined that the 
EU embraced democratic norms, standards and language. Within this context, critics could no longer lambast the EU for a lack of democracy but instead had to talk of a European democratic deficit. The deficit was evocative of the gap that existed between on the one hand the aspirations that had been generated through the application of the democratic principle to the European level, and the EU's institutional-constitutional design and actual operational practice on the other.

Since Maastricht, the EP has 'managed to establish a link between a general public discourse about European democracy and a specific programme of institutional reform, ${ }^{27}$. The EP's subsequent development has led Hix et al. to conclude that 'In a rather short space of time, a matter of decades rather than centuries, the European Parliament has evolved from an unelected consultative body to one of the most powerful elected assemblies in the world. ${ }^{28}$ We see the EP's role on the one hand as somewhat less pronounced than what Hix et al. do (notably in the realm of EU foreign and security policy), and on the other hand we also see the EP as an intrinsic part of a - distinct - multilevel structure of representative government in the EU.

How can we account for this development? To do so we must convert the institutional variant of deliberative theory into an analytical framework capable of explaining the dynamic process of EU democratization.

\section{Mechanisms of democratisation}

No single overarching theory - be it liberal intergovernmentalism with its rational choice assumptions $^{29}$ or neo-functionalism with its premise on spill-over processes from 'low' to 'high politics ${ }^{30}$ - has thus far been able to explain how non-coercive integration - with a democratic imprint - has come about. Given this it is better to approach the problem at a less general level from a middle-range theoretical perspective - and inquire into the institutions and procedures that 
are conducive to democratization. This naturally leads us to focus on mechanisms that mediate between events and convert initiatives into practical results. Mechanism-explanation represents an alternative to the covering-law model of explanation which entails subsuming an event or a phenomenon under a general law and with reference to the conditions that make the law applicable in a specific case. In contrast mechanisms can explain why an event happened postfactum. They do not predict. Mechanisms trigger actions under conditions of indeterminacy and do not determine outcomes. ${ }^{31}$

A characteristic feature of the process of forging European-level democracy is that it takes place in a setting of already existing representative democracies. Another characteristic is that this is a gradual and step-wise process that has unfolded within a broader (EU) setting that lacks an explicit polity template. This in turn has given the democratization process its distinct shape (akin to a multilevel field).

In this setting a strong impetus for European-level democratization has emanated from the mutual interaction and interweaving of the EU-level and the national level. As part of this national systems transfer democratic credos and institutional arrangements to the EU-level and the latter copy and emulate democratic credos and institutional arrangements and incorporate the role perceptions and frames that the national democratic patterns bring to and entrench in the European pattern of integration. We should therefore expect the process to activate such institutional mechanisms as framing, copying, and isomorphic pressure; the process may exhibit strong elements of path-dependency but also be susceptible to sudden external shocks. Such mechanisms and factors that initiate and condition change are found in neo-institutional theory which emphasises the endogenous nature of political institutions. ${ }^{32}$

Neo-institutional theory is however not set up to accommodate justification. It is based on a contextual rationality, where 'the rationality of the action is measured according to how well it 
fits norms.. ${ }^{33}$ This approach is limited in several respects. First, there is no means or device for rank-ordering norms in order of importance. The contextual logic posits that democratic norms can be transposed to the European level insofar as the latter makes up a norm-context that is congruent with that of the democratic Member States. But that is precisely the question in the EU: a key challenge for the EU has been to come up with convincing justifications for which democratic norms that are applicable to this unique setting. The very notion of a post-national, European democracy is contested. It was precisely in response to this question that the transnational governance approach to EU democracy was devised. To account for EU democratization we therefore need a set of mechanisms that are attuned to the logic of justification based on normative rationality; to cross-cutting, inter-contextual deliberation.

Second, to avoid black-box and deterministic explanations, and to sustain the link between justification and organisational principle we need to see institutional mechanisms as embedded in social processes of sense-making and explanation. In order to understand when and how such mechanisms as copying or emulation operate we need to see them as socially defined action coordination mechanisms. For them to function as action drivers they need to be interpreted, communicated, recognized and converted into action schemes by agents' collective efforts. Deliberative theory explains by referring to the substantial reasons the actors actually give and their uptake, which depends on whether the reasons are good enough to motivate others to approve of them. ${ }^{34}$ It comes with the following explanatory mechanisms: claims-making, justification and learning. These work in sequences. They operate through the compelling force of the better argument, that is, through the publicness, the normative power and the reasonableness of reasons that the actors consciously act upon. When claims-making triggers justification and learning, there is a case for deliberative theory. Normative learning is about how to make successful justification effective. When actors have learnt and reached an agreement 
justified claims are adopted. In cases where conflicts of interests prevail, and no agreement is in sight because of the entrenched power constellations, normative learning entails agreement on which procedures to choose for conflict resolution. Normative learning entails agreeing on justified principles for how to deal with claims-making in problematic situations. Deliberation terminates in procedurally regulated bargaining and/or in voting when actors realize that there is profound disagreement and exit is not an option. ${ }^{35}$

This approach suggests that when there is agreement on basic norms such mechanisms as copying and isomorphism may work. The more compelling the agreement, the greater the congruence, and the greater the overall thrust of these mechanisms. But when there is conflict and contention over norms and institutional arrangements, deliberative theory posits that mechanisms such as claims-making, justification and learning will come into play.

These observations bring up a number of considerations with implications for how we should analyse EU democratization from a deliberative perspective because the development and entrenchment of democratic arrangements in the EU occurs through contestation and politicization as well as through a process of overt or even tacit acceptance of democratic arrangements. ${ }^{36}$

In the following we seek to identify these mechanisms and how they have shaped EU democratization. The actors' sheer familiarity with and acceptance of representative democracy condition their justificatory demands. Europe's density of democratic norms and arrangements (historically at the Member State level but increasingly also at the European level) helps to ensure that such demands are carried by many institutional arrangements, which give impetus to the democratizing mechanisms and facilitate copying and emulation. These processes are given added impetus in particular triggering moments, events or episodes when actors are demanding reforms. In the EU this has to a considerable extent been made to operate in a recursive manner 
where actors propound norms, institutions help to ensure that common understandings are being fostered; they provide arenas where actors can put forth demands for justifications in an ongoing manner; procedures ensure that such justifications are forthcoming and learning is institutionalised; and veto points that activate publics (such as popular referenda) offer a set of additional safeguards for justification. Our assumption, then, is that this sequence has not only come into play in the EU but it has taken a distinct shape: There is basic agreement on democracy and the need to entrench this in representative form but there is also profound disagreement over how and where to locate this democracy. Post-national democracy is contested. This has prevented the sequence from coming full circle and has helped produce the distinct mode of representative-deliberative democracy that marks the EU's current multilevel configuration.

To illustrate the particular configuration of democratizing mechanisms in the EU, we start with the main claims-makers.

\section{Forging European Democratization}

In the EU a broad range of actors, including key personalities, core Member States, and EU institutions have made claims for EU representative democracy from the Communities' very inception. There were democratic federalists in the driving seat (in Member States and at the EUlevel), and federalists and integration proponents in general supported a close semantic link between democracy and the parliamentary principle. Jean Monnet, for instance, claimed early on that 'In a world in which government authority is derived from representative parliamentary assemblies, Europe cannot be built without such an assembly ${ }^{37}$; Altiero Spinnelli wrote the Ventotene Manifesto for a federal Europe in 1942 and was instrumental in bringing the EP about $;{ }^{38}$ Joschka Fischer in 2000 launched the constitutional debate in Berlin's Humboldt 
Universität, and called for a transition from a Staatenverbund to a fully parliamentarised federation. Member States have also been important: At the time of the EU's founding, the German delegation to the Schuman Plan negotiations propounded the federal democratic state as its normative template, and has held on to it since. Most of the EU's institutions have at various times acted as central agents for democratization. From the early stages, as noted, the EP has propounded the dual legitimation of the Union (citizens and states), and the need for entrenching the EU on democratic principles. The ECJ early on embraced fundamental rights as a key principle of EU law and contributed to strengthen the role of the EP. This development was given further symbolic and substantive weight with the Maastricht Treaty's entrenching of European citizenship. These comments reveal that the mechanisms of copying and emulation have played an important role, and central carriers of these have been institutional actors.

Copying and emulation are never automatic but operate in a broader structure of claimsmaking and demands for justifications. Critics and integration sceptics of all forms and stripes have constantly underlined the need to ensure that the integration process must comply with democratic norms, and have underscored the need to protect democracy in the face of European integration. The critics have consistently held up parliamentary democracy as the appropriate standard to match EU-level democracy against. ${ }^{39}$

\section{Institutionalized deliberation and isomorphic pressure}

These claims have become- to different degrees - entrenched in legal-institutional arrangements and have amounted to significant institution-carried impetuses for further democratization, with clear knock-on effects on procedural arrangements, modes of popular consultation, transparency, and openness. Maastricht, as noted, shifted the terms of discourse so that from then on the democratic deficit label was affixed to the EU. But well before that the EU had established 
various institutions and procedures to ensure institutionalised deliberation. In the Council, the Commission and the EP as well as in committees and policy-networks, representatives from Member-State governments and from citizens, with different backgrounds and on the basis of divergent political affiliations, have long been brought together in common forums to find a legitimate basis for problem-solving and conflict resolution. Because the EU's formal instruments of power are weak, ensuring agreement is an essential part of the nature of EU decision-making. This system is set up as, and functions as, a consent-based system, where unanimous voting procedures go together with more complex processes and procedures for deliberation and sounding out. Very substantial resources are expended to foster and ensure consensus and to work out disagreements over the different institutional-democratic visions that the participants bring into play. Non-agreement is difficult for such joint-decision systems, as it leads to loss of control and reduces the '...independent capabilities of action over their member governments. ${ }^{, 40}$ It leads to loss in efficiency, as well as in legitimacy. The requirement of consensus is apparent in the institutional structure, and in the relations among the institutions. For instance, 'resort to explicit majority voting is often viewed as something of a political failure...' The undertakings and procedures employed prior to decision-making indicate that the EU practises a kind of extreme consensus democracy. ${ }^{41}$

The EU's practice and institutional make-up support the notion of a non-coercive, consensual decision-making system which lends itself well to step-wise processes of democratization through institutional and procedural tinkering. But it is also a system that is prone to democratically unauthorised integration through stealth and even non-decisions. ${ }^{42}$ Necessary decisions are not made or they are very often 'delayed'.

The EP's development cannot be explained with reference to the EP alone, it is part of a much broader structure that conditions its development. This is well illustrated by the fact that the 
EP's institutional role has been systematically increased in treaty amendment processes it has been formally excluded from. The EP's development has been greatly shaped by the fact that it forms an intrinsic part of a broader organisational field made up of parliamentary-representative governments based on a particular set of discursive codes, and legitimating principles, which relates back to the development of the EU within a context of already existing - mainly parliamentary - democracies. The multilevel EU thus contains a distinct European multilevel parliamentary field made up of the Member States' parliaments, the EP and the party systems. They operate as transmitters of organizational practices and structures among their participating organizations. Such a parliamentary organisational field can therefore be conceived of as a collection of organizations that constitutes a segment of actors, norms and roles, which is marked by connectedness and some element of structural equivalence. ${ }^{43}$

The field is sustained through patterns of interaction based on shared functions and role perceptions, namely representing people's interests in EU decision-making. What distinguishes it as a parliamentary field is the character and density of inter-parliamentary interaction; the character of the field's constitutive units (parliaments); and the manner in which these two dimensions interact to give overall shape to the field.

Through the EP's development many of the national parliaments and their popular constituencies have exerted normative, coercive and mimetic isomorphic pressures on the EUlevel, and notably on the EP, to comply with the principle of parliamentary democracy.

Normative pressure relates to the fact that only parliaments have achieved the competence to speak for the people - they represent the code for the institutional embodiment of popular sovereignty. The EP has - given the inherent legitimacy of the parliamentary principle - been able to utilise its normative advantage in a communicative manner to sway others to increase the EP's role and status. The EP has then over time also acquired more formal means of power. 
Normative pressure has been complemented by additional increments of coercive and mimetic pressure.

Coercive pressure relates for instance to the pressure exerted on the EP by national parliaments to comply with representative democratic norms. Such pressures have been exerted directly on the EP but also on the legal-institutional framework that defines the EP's role within the EU system. This latter pressure has been important because the EP's own means to enhance its power and status have been weak. Several national parliaments have for instance included the EP in Treaty-amendment processes through loaning it their vetoes. ${ }^{44}$ In that sense national parliaments have explicitly albeit informally affirmed the constitutive role of the EP in the development of the EU's constitutional structure. The EP's gradually expanding powerbase has in turn rendered it more effective as a co-legislator with the Council and in controlling the election of Commissioners (the EP was for instance active in the dismissal of the Santer Commission in 1999).

Mimetic isomorphic factors relate to the fact that it is 'impossible' to come up with a viable alternative to the parliamentary model of democracy, as it is deeply embedded in institutional form, in social and cultural expectations, and in the organizational technologies of modern states. The EP was itself from its inception entrenched in a parliamentary network, as it was initially made up of national parliamentarians. From its very founding some national political parties and parliaments sought to apply the parliamentary standard to the assembly that became the EP. But until 1979 when direct elections were installed, the institution lacked the core legitimating component of any real parliament, namely direct popular representation. The isomorphic pressures exerted upon the EP from outside have since then become increasingly well reflected in the terminology - the copying of all the relevant parliamentary terminology; in the EP's composition, operating procedures and working methods; as well as increasingly so also in 
its functions. These isomorphic pressures were sustained through participation in interparliamentary networks (such as the Conference of European Affairs Committees (COSAC) and assizes), and through the EP's own propounding of the need for the EU to embrace the parliamentary principle as the key to its democratic legitimacy.

In order to account for the European democratization process it is therefore necessary to attend to the model power of the parliamentary template of representative democracy; normative and isomorphic, rather than merely, coercive, pressures. Communicative power created through public claims-making and justification triggered by criticism has 'deliberatively encoded' these processes of copying and emulation.

This form of communicative power also posits a dialectic relationship between public reaction and resentment in civil society and institutional response at the polity level. Wielding communicative pressure presupposes the existence of cherished and non-controversial principles, in this case the parliamentary principle. It reflects the learning that has taken place in Europe with regard to proper democratic rule, which helps explain why much of this process does not unfold as a struggle but as a less dramatic and less noticeable process of copying and emulation.

\section{Compelling justification}

Rittberger as noted above has observed that prior to the early 1990s there was little public discussion of the EU's democratic credentials. ${ }^{45}$ But the system has numerous built-in mechanisms for compelling reason-giving, justification and self-reflection. Critical scrutiny, judicial review, an ombudsman arrangement, transparency and openness clauses have been put in place. They ensure inclusion and hearing of different interests and their claims. Such constraints on decision-makers spur reflexivity and learning and their propensity to employ impartial reasons when responding to criticism. An important part of this, are popular referenda. They are 
opportunities for citizens to exercise veto; they help to entrench the democratic principle as a relevant reference within the process of justification. Treaty changes require unanimity, and each state decides the procedure for how to ratify. At every instance of Treaty change, some states organize referenda (some are constitutionally required to do so). Nevertheless, where popular referenda are held, they so to say 'take the public voice' and implicitly claim to speak for the entire European public. Because the general democratic code is shared, there are system-wide effects of individual referenda. Negative referendum results have been interpreted as testimony to the fact that the Union is democratically deficient; thus the long-term response to the referenda rejections has included further democratic reforms to prevent future referendum rejections. These reforms have again relied on the parliamentary principle, thus even direct democratic openings have given impetus to the EU's further parliamentarisation.

In this manner, representative parliamentary democracy has come to figure as the overarching norm that both proponents and opponents refer to, although they relate this to different conceptions of the EU (with Euro-sceptics still favouring nation-state representative democracy and Euro-federalists EU-level democracy). They disagree strongly on this organisational matter. In turn, what we find is a structure that stops short of full-fledged EU-level parliamentarisation and with national parliaments, individually and collectively, directly involved in EU-level decision-making. This structure builds on a unique configuration of representation and deliberation.

\section{Justifying representation in a changing world}

The particular configuration of mechanisms of claims-making, justification, and copying/emulation make it possible to account for the development of a system of representative 
government at the EU-level, and in a non-state context. An important reason for this relates to the fact that the pattern of claims-making and justification has focused on those representativedemocratic arrangements that were already established in the Member States. There was never support for a full-fledged transfer of these to the EU-level. Changes in the realm of international law have made state sovereignty more conditional on compliance with the "sovereign citizen" (as a holder of human rights). Such global and regional-Europeanhuman rights clauses made representative democracy more readily acceptable at the European Union level because parliaments are representative bodies for citizens and can with courts be understood as essential protectors of citizens' rights. The broader international normative learning process that brought forth the notion of citizens' inalienable rights has therefore also given support to this institutional development, whose purpose it was to ensure that the polity contains a complement of institutions that offer mutually reinforcing sustenance of citizens' basic rights.

These international changes have in turn also marked the EU's relation to future members (and associated states). The EU has developed through successive waves of so-called enlargements to less well-entrenched democracies in the South and the East. Given their frail nature this may be thought to have weakened the democratizing thrust over time, but there is a clear case for the opposite: the different rounds of enlargement have continued to give impetus to a justificatory process with democratizing effects. This stems from the fact that the EU is made up of democratic states exclusively, with democracy and rule of law as explicit entrance requirements and a system of close monitoring to ensure compliance. ${ }^{46}$ This has isomorphic effects. The EU projects democratic norms institutionally entrenched in representative government beyond its own borders, and this very projection, feeds back on the EU itself: Would the EU itself qualify for EU-membership if it applied? The EU's external projection of this principle (unto applicants), on pain of performative self-contradiction, induces the internal 
application of the principle, at the EU and Member State level. This has generated a selfreinforcing virtuous cycle.

How strong this cycle is hinges on how well the distinct form of EU parliamentarisation is able to deal with a number of central democratic challenges. The EU system is as noted embedded in a European multilevel parliamentary field. In this structure deliberation is needed to spell out the conditions and terms of representation because it is not clear at the outset what is to be represented by whom. Hence it brings about what Saward has termed the Representative claim - 'seeing representation in terms of claims to be representative by a variety of political actors' rather than as a fixed category emanating from elections ${ }^{47}$. While 'statists' (such as Rittberger and Hix) underline the mainstreaming of representation in the EU, transnationalist tend to discard it. Our position is that representation is a salient and important feature of the multilevel constellation that makes up the EU, but its organisational manifestation is contested. The EU's distinct representation-deliberation interface has also been under-theorised.

One challenge pertains to the determination of the representatives' respective mandates, which need to be sorted out in a system of overlapping competencies. Another complementary challenge pertains to the question of constituency. Who is the demos? The development of EUdemocracy is a complex process where the construction of the EU-level constituency takes place with an attendant re-construction of (national and regional) constituency. ${ }^{48}$ How this is worked out has important implications for the nature of democratic autonomy and accountability. The forging of accounts is a deliberative process, and must be so notably in the EU due to the sheer number and range of actors in the field. The interweaving of levels and competences in the EU suggests that the three processes of spelling out mandates, constructing/reconstructing constituency, and clarifying autonomy and accountability relations will be dynamic. What is to be represented by whom must be established through debate because there is no template 
available. The democratic merit of this process will hinge on the quality of the justifications it is able to bring to the table.

\section{Conclusion}

In this article we set out to account for why the main pattern of EU democratization has unfolded not along the lines that the proponents of the EU as a system of transnational governance have propounded, but rather along the lines of an EU organized as a - distinct - system of representative parliamentary government. EU democratization has since its inception drawn on the parliamentary principle and representative democratic standards; this has facilitated the creation of shared meanings and transactions among the relevant organisations; it has formed the basis for actors' legitimacy and status; it has conveyed organizational guidance and working procedures; and it has served as a constant impetus for the strengthening of the EP. This arrangement stops short of full-fledged EU parliamentarisation as vestiges of the EU's pillar structure still remain; given the EP's limited role in these (II and III), the EP falls short. This does not change very markedly with the Lisbon Treaty which formally abolishes the pillar structure, but nevertheless contains a range of provisions that protect most of the vestiges of the second pillar, with deleterious democratic effects.

We have sought to demonstrate that the EU's democratization is best understood from a deliberative democratic perspective, albeit through a new - institutional - variant, which understands justification as taking place through reference to the actors' agreed-upon standards. This variant is able to capture the distinct features of EU democratization, namely that it unfolds in a context of already existing representative-democracies, but takes on a distinct shape that is in need of further theoretical elaboration and justification. The actors have to a large extent shared 
the same democratic principles and have also agreed on the merits of representative democracy but have disagreed over the idea of post-national democracy, and also over what representation at the European level entails. The disagreement has not prevented the forging of a multilevel system of tightly interwoven parliaments. But the structure that has been wrought nevertheless brings up a number of important challenges for the theory and practice of democracy.

\section{Notes}

${ }^{1}$ Joshua Cohen and Charles Sabel, "Directly-Deliberative Polyarchy”, European Law Journal, 3 , 4(1997), 313-42; Joshua Cohen and Charles Sabel, "Sovereignty and Solidarity EU and US", In Governing Work and Welfare in a New Economy, ed. Jonathan Zeitlin and David M. Trubek, (Oxford: Oxford University Press, 2003), 345-75; James Bohman, Democracy across Borders. From Dêmos to Dêmoi. (Cambridge, MA: MIT Press, 2007).

${ }^{2}$ Cohen and Sabel, "Directly-Deliberative,"

${ }^{3}$ Bohman, Democracy.

${ }^{4}$ Berthold Rittberger, Building Europe’s Parliament. (Oxford: Oxford University Press, 2005).

5 Simon Hix, Abdul G. Noury and Gérard Roland, Democratic Politics in the European Parliament. (Cambridge: Cambridge University Press, 2007).

${ }^{6}$ Julie Smith, Europe's Elected Parliament. (Sheffield: Sheffield Academic Press, 1999).

${ }^{7}$ Glyn Morgan, The Idea of a European Superstate. (Princeton: Princeton University Press, 2005).

${ }^{8}$ Reference to author.

${ }^{9}$ The best account of the development of the EP is Rittberger's Building Europe's Parliament, which highlights legitimating beliefs. This notion confounds democracy as a principle of 
justification and as an organisational form and relies on the deliberative mechanisms we spell out for its effective operation.

${ }^{10}$ Ben Crum and John E. Fossum, "The Multilevel Parliamentary Field - A Framework for Theorising Representative Democracy in the EU", European Political Science Review 1 (2009), 249-271.

${ }^{11}$ Karlheinz Neunreither, "The Democratic Deficit of the European Union: Towards Closer Cooperation between the European Parliament and the National Parliaments", Government and Opposition 29, 3 (1994), 299-314; Karlheinz Neunreither, "The European Parliament and National Parliaments: Conflict or Cooperation?" In The Europeanisation of Parliamentary Democracy, ed. Katrin Auel and Arthur Benz (London: Routledge, 2006), 164-187; Andreas Maurer and Wolfgang Wessels (eds), National Parliaments on their Ways to Europe: Losers or Latecomers? (Baden-Baden: Nomos, 2001).

12 James Johnson, “Arguing for Deliberation: Some Sceptical Considerations”, In Deliberative Democracy, ed. Jon Elster (Cambridge: Cambridge University Press, 1998), 161-174.

${ }^{13}$ John Dewey, The Public and its Problems, (Chicago: Gateways Books, 1927), 207.

${ }^{14}$ Hauke Brunkhorst, "A polity without a state? European constitutionalism between evolution and revolution", In Developing a Constitution for Europe, ed. Erik O. Eriksen, John E. Fossum and Agustin J. Menéndez (London: Routledge, 2004), 88-105; Rainer Schmalz-Bruns, "On the political theory of the Euro-polity”, In Making the European Polity: Reflexive integration in the EU, ed Erik O. Eriksen (London: Routledge, 2005), 59-83.

15 For the epistemic argument in this regard, see Jürgen Habermas, The Postnational Constellation: Political Essays, (Cambridge: Polity Press, 2001), 110; David M. Estlund, 
Democratic Authority. A philosophical framework, (Princeton: Princeton University Press, 2008), 97.

${ }^{16}$ Reference to author.

${ }^{17}$ Carl Schmitt, The Crisis of Parliamentary Democracy. (Cambridge, MA: MIT Press, 1926 [reprint, 1992]); Larry Siedentop, Democracy in Europe. (London: Penguin, 2000), 45.

${ }^{18}$ Ernest Barker, Reflections on Government. (Oxford: Oxford University Press, 1942).

${ }^{19}$ A strong public is an open deliberative space, in which deliberation takes place prior to decision-making, and where decision-makers are held to account (cp. Nancy Fraser, "Rethinking the Public Sphere: A Contribution to the Critique of Actually Existing Democracy”, In Habermas and the Public Sphere, ed. Craig Calhoun (ed.) (Cambridge, MA: MIT Press, 1992), 109-42.

${ }^{20}$ Bernhard Manin, The Principles of Representative Government, (Cambridge: Cambridge University Press, 1997), 192; John Stuart Mill, Considerations on Representative Government (London: Dent, 1861[reprint, 1984]).

${ }^{21}$ Mill, Considerations, 215.

${ }^{22}$ Manin, The Principles, 190.

${ }^{23}$ Martin Westlake, A Modern Guide to the European Parliament, (London: Pinter, 1994), 16.

${ }^{24}$ Stephen Day and Jo Shaw, "The evolution of Europe's transnational political parties in the era of European citizenship", In The State of the European Union, Vol. 6: Law, Politics, and Society, ed. Tanja A. Börzel and Rachel A. Cichowski (Oxford: Oxford University Press, 2003), 150.

${ }^{25}$ Berthold Rittberger and Frank Schimmelfennig, "Explaining the Constitutionalization of the European Union", Journal of European Public Policy, 13,8 (2006), 1148-67, 1149.

${ }^{26}$ Rittberger, Building, 28. 
${ }^{27}$ Thomas Christiansen, "Supranational actors in EU treaty reform", Journal of European Public Policy, 9 (2002), 33-53, 45.

${ }^{28}$ Hix et al. Democratic Politics, 3.

${ }^{29}$ Andrew Moravcsik, The Choice for Europe: Social Purpose and State Power from Messina to Maastricht. (London: UCL Press, 1998).

30 Ernst B. Haas, "International integration: the European and the universal process", International Organization, 15, 3(1961), 366-92.

31 Jon Elster, Explaining Social Behavior. More Nuts and Bolts for the Social Sciences, (Cambridge: Cambridge University Press, 2007), 36.

${ }^{32}$ James G. March and Johan P. Olsen, Democratic Governance. (New York: The Free Press, 1995).

${ }^{33}$ Reference to author.

${ }^{34}$ Reference to author.

${ }^{35}$ Reference to author.

${ }^{36}$ On this, see Lisbeth Hooghe and Gary Marks, "A Postfunctional Theory of European Integration: From Permissive Consensus to Constraining Dissensus”, British Journal of Political Science 39, 1 (2009), 1-23; Doug Imig, "Contestation in the streets: European Protest and the Emerging Euro-polity", Comparative Political Studies 35,8(2002), 914-33; Doug Imig and Sidney Tarrow, Contentious Europeans: Protest and Politics in an Emerging Polity. (Lanham, MD: Rowman and Littlefield, 2001).

${ }^{37}$ Rittberger, Building, 1.

38 See Agustin J. Menéndez (ed.) "Altiero Spinelli - From Ventotene to the European Constitution"” RECON Report No 1, Oslo: ARENA, 2007. Available at: 
$<$ http://www.reconproject.eu/projectweb/portalproject/Report1_Spinelli.html $>$.

${ }^{39}$ Siedentop, Democracy; Rittberger, Building.

${ }^{40}$ Fritz W. Scharpf, “The Joint-decision Trap: Lesson from German Federalism and European Integration", Public Administration 66, 3(1988), 239-78, 258.

${ }^{41}$ Chris Lord, Democracy in the European Union. (Sheffield: Sheffield University Press, 1998), $47-8$.

${ }^{42}$ Giandomenico Majone, Dilemmas of European integration. (Oxford; Oxford University Press, 2005).

${ }^{43}$ We have adapted this terminology from Walter W. Powell and Paul J. DiMaggio, The New Institutionalism in Organizational Analysis. (Chicago: University of Chicago Press, 1991).

${ }^{44}$ During the Maastricht negotiations the Italian and Belgian parliaments formed an agreement, which stated that they would ratify the accord only if the EP had given its assent. This also applied to Amsterdam (interview with Commission official, January 1998). On 'indirect veto', see Christiansen, Supranational.

${ }^{45}$ Rittberger, Building.

46 That is according to the so-called Copenhagen criteria, see:

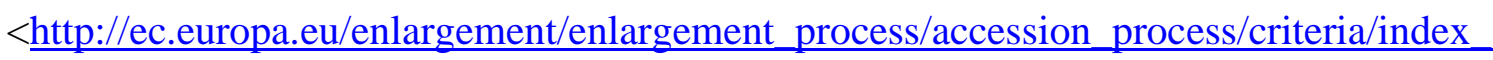
en.htm> [Accessed 21 July 2010].

${ }^{47}$ Michael Saward, "The Representative Claim", Contemporary Political Theory, 5,2 (2006), 297-318, 298.

${ }^{48}$ Reference to author. 